\title{
Impact of Select Factors on Gold Prices in India
}

\author{
Dr. Rashmi Paranjpye, Associate Professor, DY Patil B-School, Tathawade, Pune, India.
} rashmi.paranjpye@dpu.edu.in

\begin{abstract}
Gold has been preferred as an investment option by Indian investors. The other alternatives for investment are stocks, bonds and other precious metals such as silver and platinum. Indians prefer buying physical gold as there is emotional attachment. India is currently the largest importer of gold and consumes one-third of supply of gold in the world annually. BSE Sensex and Nifty are benchmark indices of the stock market. This paper aims at studying the impact of factors such as BSE Sensex, NSE Nifty and precious metals such as silver on gold prices. Statistical tools such as correlation and regression are used to identify the relation between each of these variables with gold prices. The study shows that there is positive correlation between Sensex and Gold prices, and Nifty and Gold prices. $R$ value is significant for Sensex and Nifty. Variation in Sensex and Nifty may have an impact on gold prices. There is positive correlation between Silver prices and Gold prices, but $R$ value is insignificant. Therefore variation in silver prices may not impact variation in gold prices but variation in Sensex and Nifty may impact gold prices.
\end{abstract}

Keywords: - Gold prices, BSE Sensex, Nifty, Silver prices, correlation, regression

\section{INTRODUCTION}

Gold has been preferred as an investment option by Indian investors. The other alternatives for investment are stocks, bonds and other precious metals such as silver and platinum. Risk can be diversified by investing into assets such as hedge funds, equity and bonds, real estate and commodities, precious metals such as gold, silver and platinum. In India, people invest in gold irrespective of increasing prices. This paper aims at studying the impact of other investment options such as equity and silver on gold prices. Hence monthly figures of BSE Sensex and NSE Nifty are obtained from the respective websites. Silver has long been valued as a precious metal. Silver ornaments are gaining a lot of importance. Silver is used in solar panels, water filtration, jewelry, ornaments, decorative utensils and tableware. It is also used in mirrors, photographic film. Silver compounds are used in medical instruments. Since past few years prices of silver are also increasing, hence impact of silver on gold prices is considered.

\section{RESEARCH OBJECTIVES}

1. To analyze the impact of BSE Sensex on gold prices

2. To analyze the impact of NSE Nifty on gold prices

3. To analyze the impact of prices of silver on gold prices

\section{RESEARCH METHODOLOGY}

This study aims at calculating the impact of BSE Sensex, NSE Nifty and silver prices on prices of gold. The methods used in this study are analytical and descriptive in nature. Data has been collected for a period of 7 years from January 2013 to December 2019 for every month for Nifty, Sensex, Gold prices and Silver prices. Data has been obtained from secondary sources such as RBI bulletin, NSE website (www.nseindia.com) and BSE website (www.bseindia.com) for the period of 84 months starting from January 2013 to December 2019. The data has been analyzed to evaluate the impact of Sensex, Nifty and silver prices on gold prices. The data has been analyzed using statistical tools such as correlation and regression.

Correlation is a statistic that measures the degree to which two securities move in relation to each other. Correlation coefficient greater than zero indicates positive relationship, value less than zero indicates negative relationship and value equal to zero indicates no relationship. Regression analysis is a set of statistical processes that estimate the relationship between dependent and independent variable. Sensex, Nifty and silver prices are independent variables and gold prices are dependent variable. Since Sensex, Nifty and gold are alternative investments, hypotheses are set to find out the relation between these variables.

Hypotheses:

1. Hypothesis Assumed (Ho): Gold prices do not depend upon BSE Sensex

2. Hypothesis Assumed (Ho): Gold prices do not depend upon NSE Nifty

3. Hypothesis Assumed (Ho): Gold prices do not depend upon Silver Prices

\section{LITERATURE REVIEW}

Sharma S.(2018)[1] in the paper 'Determinants of Gold prices in India' has identified the reasons for buying gold. There is positive correlation between BSE Sensex, crude oil prices and personal disposable income and gold prices and their combined effect is statistically significant. Balaji V.V. \& S. Mahalingam(2018)[2] have found that when Sensex 
increases gold prices also increase whereas when there is reduction in currency value gold prices increase. Crude oil has positive relation with gold. Shobha C.V. (2017)[3] has tried to find the factors influencing decision on kind of gold investment and whether investment in gold is a safe investment than other alternatives like stocks and bonds. The study found that factors such as age, gender, education, marital status and income are the influencing factors while investing in gold. Out of these factors education was not an influential factor. The study has been done on the Kozhikode district of Kerala.

Dr. Sindhu (2013)[4] has analyzed the factors which affect the price of gold. The paper has studied the impact of exchange rate, crude oil prices, repo rate and inflation on gold prices. There is inverse relation between dollar and gold, crude oil prices and repo rate affect prices of gold significantly. Gold prices depend upon inflation. Dr. Bhunia A. \& Mr. Amit Das (2012)[5] reveal that there exists long run equilibrium relation between gold prices and stock market returns. During global financial crisis, stock markets crashed but gold prices continued to increase in India. Gold is an integral part of social and religious customs and a basic form of savings. It is an important mode of investment. Dr. Partap Singh(2013)[6] has studied the trends in gold prices and its demand, volatility in gold prices and causes of mounting prices of gold in the Indian economy in his paper 'Gold Prices in India: Study of trends and Patterns'. The average annual growth was 12.27 percent indicating that investment in gold is safe investment. High domestic inflation rates have adversely affected jewelry demand, due to its impact on disposable income level and general consumer sentiment.

Dr. Tripathy N. \& Tripathy A.(2016)[7] have investigated the integration between Nifty and gold prices. They have used statistical tools such as time series, Unit root test, correlation test, Granger causality test and Johansson's cointegration test to evaluate the relationship. The paper mentions that in the short run there is no causal relation but in the long run there is equilibrium relationship. The stock market price can be used for prediction of gold prices. Abdullah and M.J.A Bakar (2015)[8] have determined a forecasting model of price of gold in relation to rate of interest so as to enable forward interpretation of capital market expectations. According to the paper, price of gold and real interest rates are inversely related as revealed through Gibson's Paradox. Thinkaran G. L. \& C.F .Octovia Antony Sessammal(2018)[9] have studied the correlation between gold consumption and gold investment and the impact on economy due to increase in gold consumption. High gold consumption leads to increase in current account deficit (CAD). Higher interest rates will motivate people to save money in banks and thus decrease investment in gold.

\section{DATA ANALYSIS}

\section{BSE SENSEX}

The Sensex is the benchmark index of Bombay Stock Exchange Ltd. It is the most widely tracked equity guage in India. Since February 2013 it is officially known as S\&P BSE Sensex. The index captures the performance of the top 30 largest and financially stable companies from across major sectors of India that are listed on the exchange. The Sensex reflects the state of the economy, investor sentiment and health of the equity market. In January 2013 the Sensex was 19780.26 whereas in December 2019 it rose to 41068 points, a rise of 107 percent. Gold prices in January 2013 were 30520 (Rs per 10 grams) and in December 2019 were 38092, a rise of 24 percent.

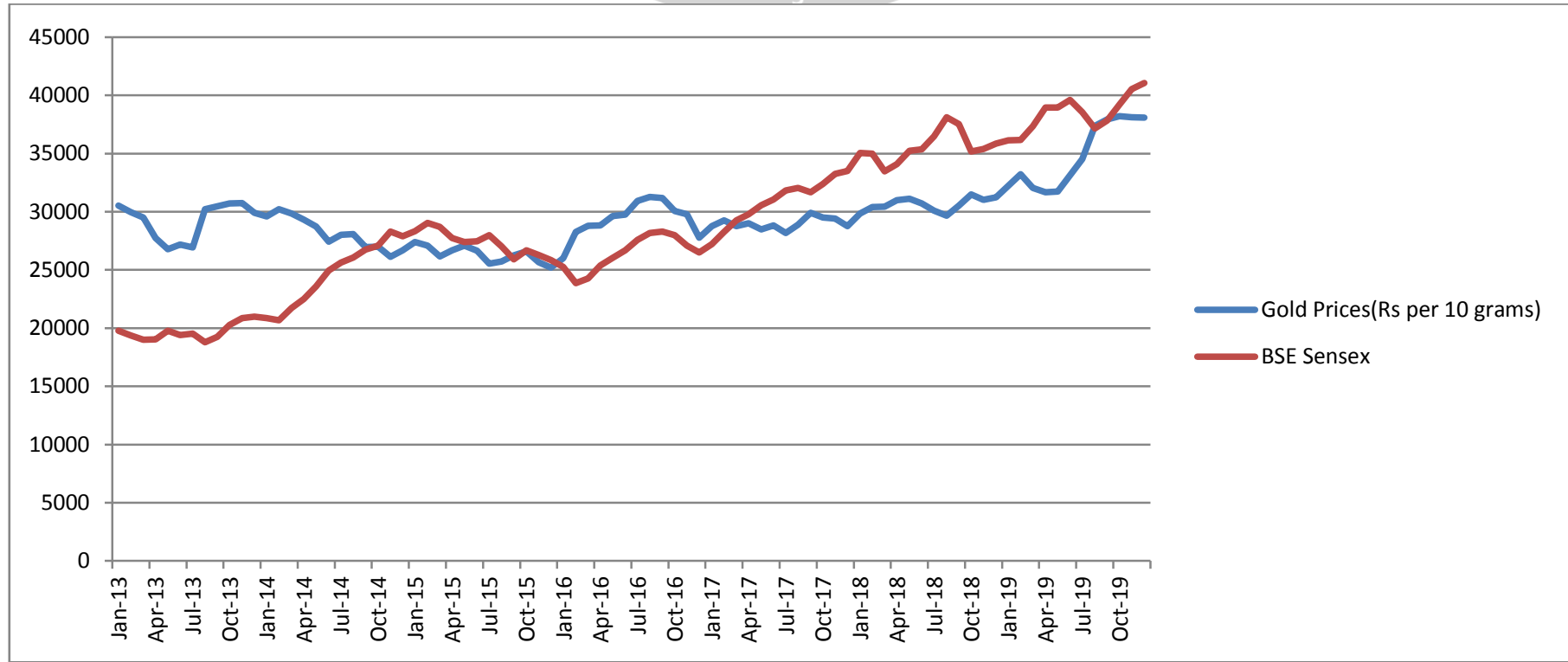

Chart 1: Trend Analysis 
The chart shows that BSE Sensex and gold prices are moving upwards in the same direction during the period January 2013 to December 2019. Sensex was 19780.26 in Jan 2013 and 41068 in December 2019. The prices of gold (per 10 grams) were Rs 30520 in Jan 2013 and Rs 38092 in December 2019.

\section{HYPOTHESIS ASSUMED (HO): GOLD PRICES DO NOT DEPEND UPON BSE SENSEX}

Table 1: Correlation between Sensex and Gold

\begin{tabular}{|c|c|c|}
\hline & Gold Prices & BSE Sensex \\
\hline Gold Prices & 1 & \\
\hline BSE Sensex & 0.579493422 & 1 \\
\hline
\end{tabular}

Table 2: SUMMARY OUTPUT

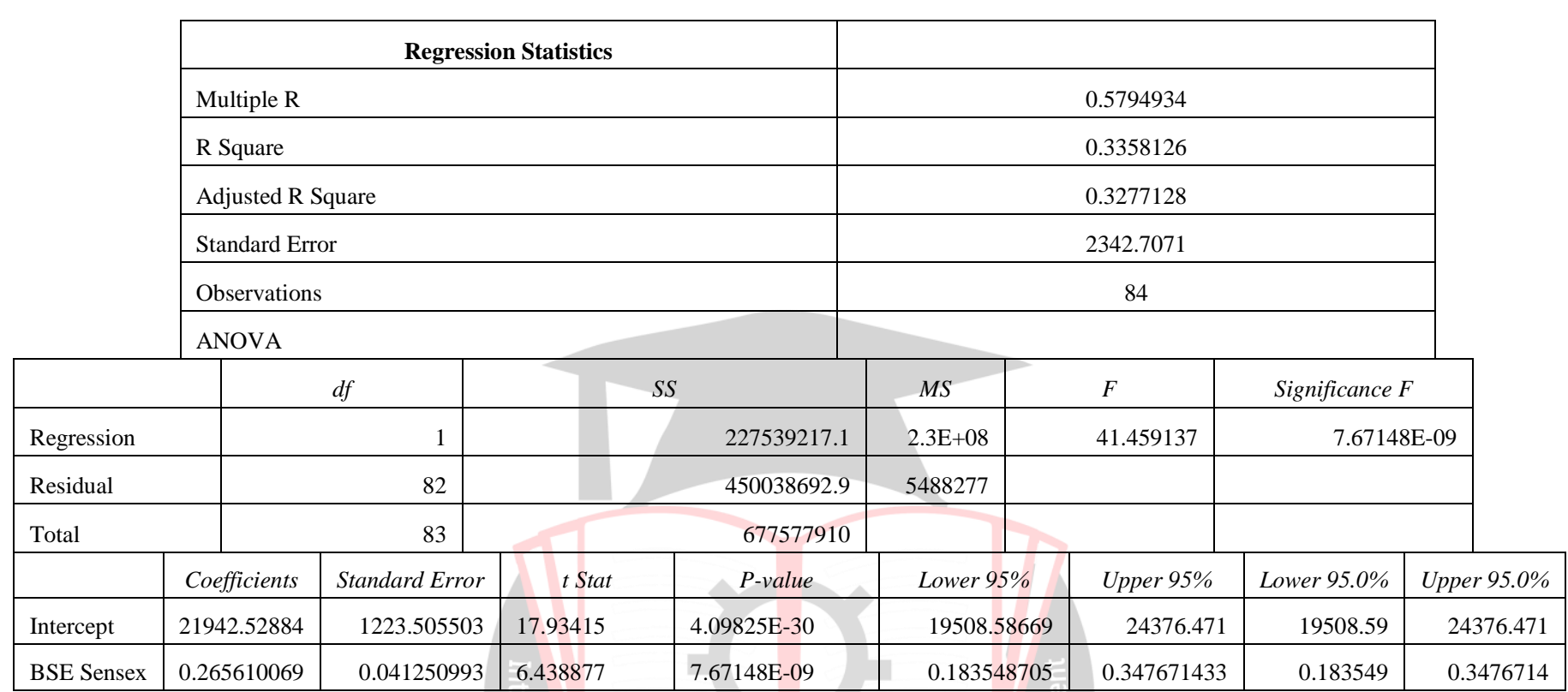

There is positive correlation between Sensex and Gold prices. Multiple R value is 0.5794934 which is significant. R square is 0.3358126 , therefore variation in Sensex can account for $33 \%$ for variation in gold prices. The chart also shows that Sensex and gold prices are moving in the same direction. There is significant linear regression with $p$-value $=0.00000000767$. The multiple R value 0.5794934 shows that there is significant correlation between Sensex and gold prices. Hence Sensex affects gold prices. R-square is 0.3358126 which shows the extent to which Sensex affects gold prices.

\section{NIFTY 50}

The NIFTY 50 index is the benchmark of National Stock Exchange of India. It represents the weighted average of 50 stocks of Indian companies across different sectors. It is the main stock index used in India. There has been $119 \%$ increase in Nifty from January 2013 to December 2019. In January 2013 Nifty was 7744.14 whereas in December 2019 it was 16975.97.

Chart 2: Trend Analysis

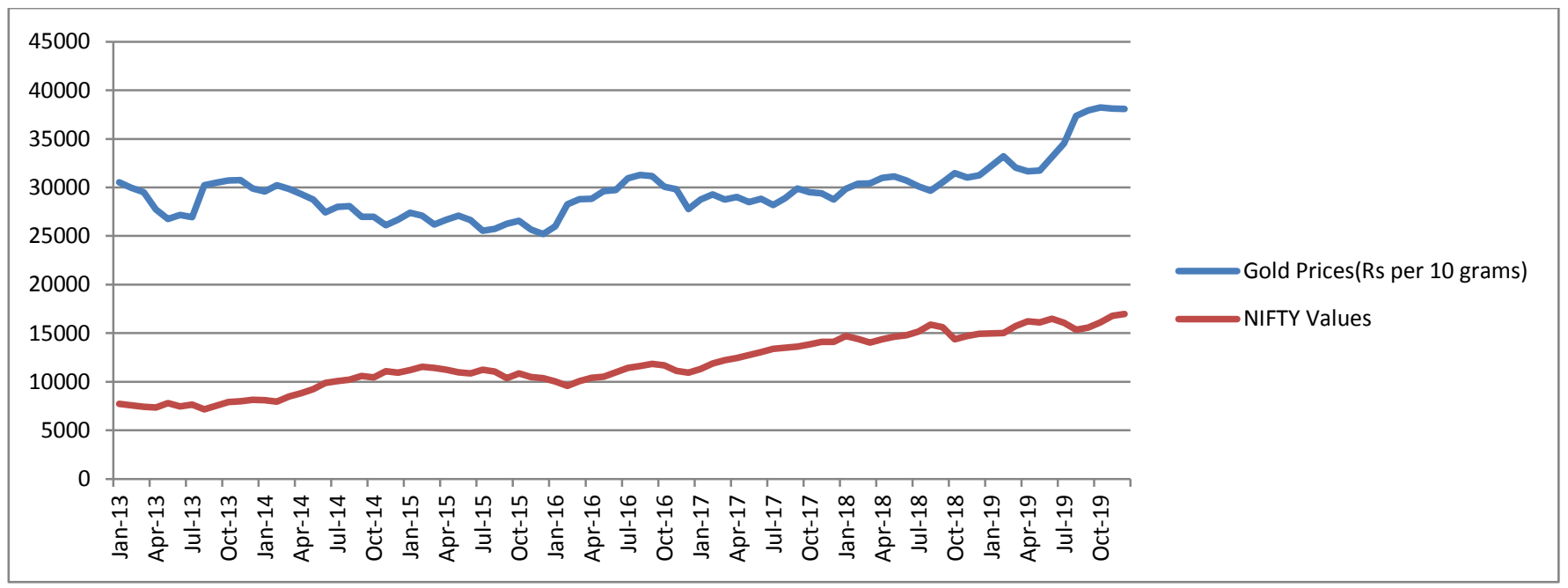


The chart implies that Nifty and gold prices are moving upwards in the same direction during the period January 2013 to

December 2019. Nifty was 7744.15 in January 2013 and 16975.97 in December 2019.

\section{HYPOTHESIS ASSUMED (HO): GOLD PRICES DO NOT DEPEND UPON NSE NIFTY Table 3: Correlation}

\begin{tabular}{|l|r|r|}
\hline & Gold Prices & \multicolumn{1}{c|}{ NIFTY Values } \\
\hline Gold Prices & & 1 \\
\hline NIFTY Values & 0.575304 & 1 \\
\hline
\end{tabular}

Table 4: SUMMARY OUTPUT

\begin{tabular}{|c|c|c|c|c|c|c|c|c|c|}
\hline & \multicolumn{4}{|c|}{ Regression Statistics } & & & & & \\
\hline & \multicolumn{4}{|l|}{ Multiple R } & \multicolumn{3}{|c|}{0.575304} & & \\
\hline & \multicolumn{4}{|l|}{ R Square } & \multicolumn{3}{|c|}{0.3309747} & & \\
\hline & \multicolumn{4}{|c|}{ Adjusted R Square } & \multicolumn{3}{|c|}{0.3228158} & & \\
\hline & \multicolumn{4}{|c|}{ Standard Error } & \multicolumn{3}{|c|}{2351.2238} & & \\
\hline & \multicolumn{4}{|c|}{ Observations } & \multicolumn{3}{|c|}{84} & & \\
\hline & \multicolumn{4}{|l|}{ ANOVA } & & & & & \\
\hline & \multicolumn{2}{|c|}{$d f$} & \multicolumn{2}{|l|}{ SS } & $M S$ & $F$ & Significance $F$ & & \\
\hline Regression & \multicolumn{2}{|l|}{1} & \multicolumn{2}{|c|}{224261122.6} & $2.24 \mathrm{E}+08$ & 40.56636 & $1.04006 \mathrm{E}-08$ & & \\
\hline Residual & \multicolumn{2}{|l|}{82} & \multicolumn{2}{|c|}{453316787.4} & 5528254 & $=$ & & & \\
\hline \multirow[t]{2}{*}{ Total } & \multicolumn{2}{|l|}{83} & \multicolumn{2}{|c|}{677577910} & & & & & \\
\hline & Coefficients & Standard Error & $t$ Stat & 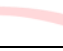 & $P$-value & Lower $95 \%$ & Upper $95 \%$ & Lower $95.0 \%$ & Upper $95.0 \%$ \\
\hline Intercept & 22703.935 & 1119.836955 & 20.27432 & & $1.1 \mathrm{E}-33$ & 20476.2227 & 24931.65 & 20476.22 & 24931.647 \\
\hline NIFTY Values & 0.5863964 & 0.092067914 & 6.369173 & & $1.04 \mathrm{E}-08$ & 0.403244034 & 0.769549 & 0.403244 & 0.7695488 \\
\hline
\end{tabular}

Similar to Sensex, there is positive correlation between Nifty and gold prices, since R value is 0.575304 . Nifty can account for $33 \%$ variation in gold prices. It can be also observed from the chart that Nifty and gold prices are moving in the same direction. There is significant linear regression with $\mathrm{p}$-value $=0.0000000104$. Multiple $\mathrm{R}$ value which is 0.575304 denotes that there is positive correlation between Nifty and gold prices. Value of R square is 0.3309747 tells us that Nifty can affect $33 \%$ of variation in gold prices.

\section{SILVER PRICES}

Silver has long been valued as a precious metal. It is a chemical element with very high electrical conductivity and thermal conductivity. Indian women prefer silver jewelry as well along with gold ornaments. Hence silver metal has been considered. In January 2013 price of silver per $\mathrm{kg}$ was Rs 58732, whereas in December 2019 it is Rs 44576 per $\mathrm{kg}$. There has been a decrease of $24 \%$ in the price as compared to January 2013 price but silver is gaining a lot of importance. Silver is used in solar panels, water filtration, jewelry, ornaments, decorative utensils and tableware. It is also used in mirrors, photographic film. Silver compounds are used in medical instruments.

\section{Chart 3: Trend Analysis}

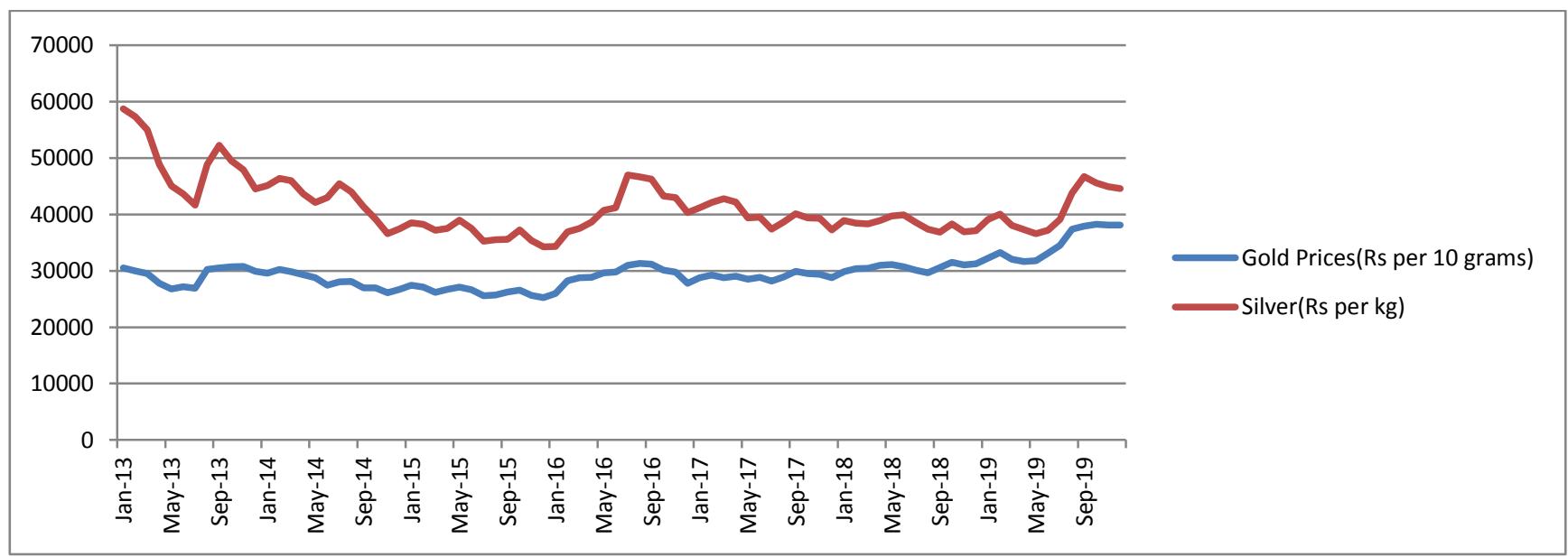


Chart 3 depicts that although gold and silver prices are moving similarly since October 2016, silver prices have fallen significantly from January 2013 to June 2013. There is an upsurge in silver prices in October 2016. In January 2013 silver prices were Rs 58732 (per kg) and in December 2019 Rs 44576(per kg).

\section{HYPOTHESIS ASSUMED (HO): GOLD PRICES DO NOT DEPEND UPON SILVER PRICES}

Table 5: Correlation

\begin{tabular}{|l|r|r|}
\hline & Gold Prices & \multicolumn{1}{c|}{ Silver } \\
\hline Gold Prices & 1 & 1 \\
\hline Silver & 0.313086911 & 1 \\
\hline
\end{tabular}

Table 6: SUMMARY OUTPUT

\begin{tabular}{|l|c|}
\hline \multicolumn{1}{|c|}{ Regression Statistics } & \\
\hline Multiple R & 0.313086911 \\
\hline R Square & 0.098023414 \\
\hline Adjusted R Square & 0.087023699 \\
\hline Standard Error & 2730.048267 \\
\hline Observations & 84 \\
\hline
\end{tabular}

ANOVA

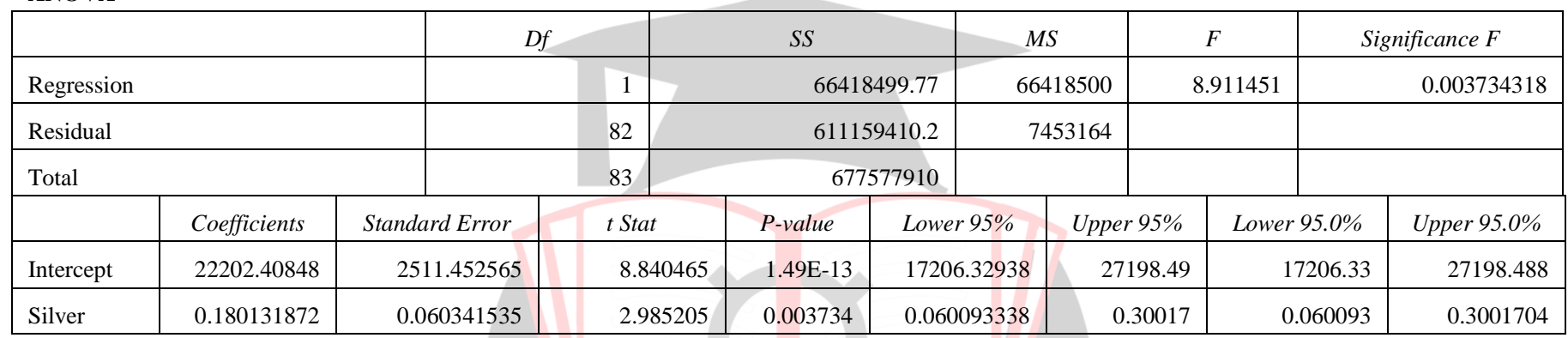

There is positive correlation between Silver prices and Gold prices, but since $\mathrm{R}$ value is 0.313086911 correlation is insignificant. $\mathrm{R}$ square is 0.098023414 which implies that variation in Silver prices need not impact variation in gold prices. The $\mathrm{p}$-value $=0.003734$ which shows that the linear regression between silver and gold prices is insignificant. Since R-Square is 0.098023414 which is not close to 0.5 makes it insignificant. Multiple $\mathrm{R}$ value is 0.313086911 that the relation between silver and gold prices is insignificant.

\section{FINDINGS}

\section{HYPOTHESIS ASSUMED (HO): GOLD PRICES DO NOT DEPEND UPON BSE SENSEX}

There is positive correlation between Sensex and Gold prices. Multiple $\mathrm{R}$ value is 0.5794934 which is significant. $\mathrm{R}$ square is 0.3358126 , therefore variation in Sensex can account for $33 \%$ for variation in gold prices. The chart also shows that Sensex and gold prices are moving in the same direction. There is significant linear regression with $\mathrm{p}$-value $=0.00000000767$. Therefore the hypothesis that gold prices do not depend upon BSE Sensex is rejected.

\section{HYPOTHESIS ASSUMED (HO): GOLD PRICES DO NOT DEPEND UPON NSE NIFTY}

Similar to Sensex, there is positive correlation between Nifty and gold prices, since R value is 0.575304 , which is significant. Since R-square is 0.3309747 , Nifty can also account for $33 \%$ variation in gold prices. It can be observed from the chart that there is positive correlation between Nifty and gold prices as both are moving in the same direction. The $\mathrm{p}$-value $=0.0000000104$ which shows that there is significant linear regression. The hypothesis that gold prices do not depend upon NSE NIFTY is rejected.

\section{HYPOTHESIS ASSUMED (HO): GOLD PRICES DO NOT DEPEND UPON SILVER PRICES}

There is positive correlation between Silver prices and Gold prices, but since $\mathrm{R}$ value is 0.313086911 correlation is insignificant. $\mathrm{R}$ square is 0.098023414 ; it implies that variation in Silver prices need not impact variation in gold prices. The $\mathrm{p}$-value $=0.003734$ implies that linear regression between silver and gold prices is not significant. Hence the hypothesis that gold prices do not depend upon silver prices is accepted. 


\section{CONCLUSIONS}

Table 4: Consolidated Analysis

\begin{tabular}{|c|c|c|c|}
\hline & $\begin{array}{c}\text { Multiple R } \\
\text { value }\end{array}$ & $\begin{array}{c}\text { R-Square } \\
\text { value }\end{array}$ & P value \\
\hline Sensex and Gold prices & 0.579493421 & 0.335812625 & $\begin{array}{c}7.67148 \mathrm{E}- \\
09\end{array}$ \\
\hline Nifty and Gold prices & 0.575303977 & 0.330974666 & $\begin{array}{c}1.04006 \mathrm{E}- \\
08\end{array}$ \\
\hline $\begin{array}{c}\text { Silver prices and Gold } \\
\text { prices }\end{array}$ & 0.313086911 & 0.098023414 & $\begin{array}{c}0.0037343 \\
18\end{array}$ \\
\hline
\end{tabular}

In India gold is considered as a safe and liquid investment. It also has sentimental value. From the table it is evident that Multiple R value and r-Square for Sensex and Nifty are similar, whereas for silver they are different. There is also difference in the p-value of Sensex and Nifty and that of silver prices. The analysis reveals that gold prices are positively related to BSE Sensex, Nifty and silver prices. But correlation with Sensex and Nifty is significant while correlation with silver is insignificant. Sensex and Nifty may affect approx $33 \%$ gold prices but silver prices do have any impact on gold prices.

From the study it is evident that select factors like Sensex and Nifty have an impact on gold prices and the relationship between Sensex, Nifty and gold prices is significant. Although there is positive relation between silver and gold prices the relationship is insignificant. Silver prices do not have an impact on gold prices.

\section{REFERENCES}

[1] Sharma Soumya "Determinants of Gold Prices in India" International Journal of Research and Analytical Reviews (IJRAR) (2018): Vol.5, Issue 4

[2] V.V.Balaji and S. Mahalingam "A Study on Impact of Gold Prices in Various Markets - An Empirical Study" International Journal of Business and Administration Research Review (IJBARR) (2018): Vol.2, Issue 21

[3] Shobha C.V. "A study on Gold as a Safer Investment alternative among small and medium investors with special reference to Kozhikode district" International Journal of Research - Granthaalayah (2017): Vol.5, Issue 11

[4] Dr. Sindhu "A study on Impact of select factors on the price of Gold" IOSR Journal of Business and Management (IOSR-JBM) (2013): Vol.8, Issue 4, pp 84-93

[5] Dr. Bhunia A. \& Mr. Das A. "Association between gold prices and stock market returns: Empirical evidence from NSE" Journal of Exclusive Management Science (2012): Vol.1, Issue 2

[6] Dr. Partap Singh "Gold Prices in India: Study of Trends and Patterns" International Journal of Innovations in Engineering and Technology(2013): Vol.2, Issue 4
[7] Dr. Naliniprava Tripathy \& Amit Tripathy "A study on dynamic relationship between gold price and stock market price in India" European Journal of Economics, Finance and Administrative Sciences(2016): Issue 88

[8] Adam Abdullah \& Mohd Jaffri Abu Bakar (2015) "The Application of Gold Price, Interest Rates and Inflation Expectations in Capital Markets" International Journal of Economics and Finance(2015): Vol.7, No 2

[9] Thinkaran G. L. \& C.F .Octovia Antony Sessammal (2018) "An Impact of Changing Attitude from Gold Consumption to Gold Investment on an Indian Economy An Analytical Approach" International Journal for Research in Engineering Application \& Management (IJREAM), Vol 4, Issue 9, Dec 2018

[10] www.nseindia.com, www.bseindia.com, RBI Bulletin (January 2013 to December 2019) 